\title{
Serum CA 19-9 Measurement
}

National Cancer Institute

\section{Source}

National Cancer Institute. Serum CA 19-9 Measurement. NCI Thesaurus. Code C157253.

The determination of the amount of cancer antigen 19-9 present in a serum sample. 